\title{
Global synthesis reveals that ecosystem degradation poses the primary threat to the world's medicinal animals
}

\author{
Monica L. Short ${ }^{1}$ and Chris T. Darimont ${ }^{1,2}$
}

\begin{abstract}
Although overexploitation threatens some high-profile medicinal animals, little is known about global patterns in the use of - and threats to - medicinal animals. We examined data from the International Union for Conservation of Nature's Red List and a literature survey to identify a diverse catalog of medicinal animals $(n=1660)$. Most known species $(\sim 77 \%)$ are chordates in terrestrial habitats $(\sim 72 \%)$. Intensity of use generally maps to biodiverse regions with low human development. Most ( $63 \%)$ species are decreasing, and primary threats relate to habitat loss and modification. Many $(\sim 62 \%)$ species have multiple uses, which is associated with higher endangerment and threats from exploitation than species used solely for medicine. Spiritual use medicinal species have a higher proportion of "at-risk" species $(\sim 19 \%)$ than those used otherwise $(\sim 6 \%)$, potentially owing to associations among rarity, perceived efficacy, and demand. These findings can inform spatially and taxonomically explicit biocultural strategies to safeguard not only biodiversity but also important human-animal relationships.
\end{abstract}

Key Words: animals; conservation; endangerment; ethnomedicine; ethnozoology; global; medicine; threats

\section{INTRODUCTON}

Human relationships with medicinal animals are varied and have yet to be broadly synthesized. Well-known examples of highly exploited medicinal species include pangolins (Manis spp.; Boakye et al. 2014, 2015, Soewu and Ayodele 2009, Cheng et al. 2017) and rhinoceri (Rhinocerotidae spp.)(Yan et al. 2013, Cheung et al. 2018). Moreover, prominent scientific publications (e.g., Alves and Rosa 2005, Alves and Barboza 2010, Graham-Rowe 2011) and popular media (e.g., Stromberg and Zielinski 2011, Hall 2019) commonly identify overexploitation as a central concern. Against this high-profile foreground, however, is the reality that up to $80 \%$ of the global population uses plant and animal parts for traditional medicines in addition to raw materials for modern medicines (Alves and Rosa 2005). Despite this context, and the reality that animals might be particularly sensitive to human activity, little is known about global patterns of medicinal animal use and the threats these species might face. Given their history of, and contemporary use by, place-based peoples, threats to the persistence of medicinal animals also pose risk to associated traditional knowledge (Alves and Rosa 2005). Accordingly, understanding varied uses of medicinal animals and the threats they face across taxa and space can inform planning and interventions to safeguard not only biodiversity but also important human-animal relationships.

Several reviews related to particular medicinal animals have identified patterns of use. For example, there are syntheses on aquatic mammals (Alves et al. 2012b), termites (de Figueiredo et al. 2015), reptiles (Alves et al. 2008), primates (Alves et al. 2010), and canids (Alves and Barboza 2010). Other studies are predominantly regional, commonly occurring in South America and Asia (Append. 1: Methods).

Although not previously examined, geographic areas of prominent medicinal use (and threats to their use) likely occur where so-called human development is low. Generally, areas with a low human development index (HDI; United Nations
Development Programme (UNDP) 2018) have strong histories and current practice of traditional medicine (Stangeland et al. 2008). Additionally, poverty can be pronounced in many of these regions, and low access to, or trust in, Western health care is common (Liu et al. 2016). Finally, areas of higher HDI often experience greater habitat loss, which may reduce biodiversity available for medicinal use (Alves and Rosa 2007a).

Across varied geographies, threats medicinal animals face might be associated with other uses. The harvest of animals for food, for example, has shown to have profound impacts on megafauna populations (Ripple et al. 2019). Consequently, we might predict that medicinal species with multiple (i.e., other) uses might have a higher risk of overexploitation than those used solely for medicine.

There is also variation in how animals are used medicinally, which theory suggests might relate to conservation status. Treatments involving animals are manifold and broadly include addressing physical, mental, and spiritual ailments. For example, in Mexico, the meat of the greater roadrunner (Geococcyx californianus) is used to treat physical ailments including cancer and bronchitis (Jacobo-Salcedo et al. 2011). In Brazil, the white-browed guan (Penelope jacucaca) is used to treat insomnia (Alves et al. 2017). In the Afro-Brazilian religion of Candomblé, the red cushion sea star (Oreaster reticulatus) is used spiritually for attraction, protection, and enlightenment (Alves et al. 2012a).

How spiritual use might link to conservation is complex. For instance, spirituality and associated religious and cultural beliefs might offer protection from overexploitation. In other cases, spiritual use might instead make a species more desirable (Alves et al. 2012a), thereby potentially placing it at greater risk of overexploitation. Specifically, rare species might have a higher perception of medicinal efficacy. For example, a Japanese flower species, Geranium thunbergii, has red and white varieties. Across several areas, the rarer color is considered medicinally more effective (Courchamp et al. 2006). Generally, such a pattern is 
predicted by the anthropogenic Allee effect (AAE). The AAE predicts that, as species become rarer, the incentive to exploit them increases. The main assumptions upon which the AAE are based are that species rarity and value are positively correlated; such correlation can increase demand, market price, and benefit of exploitation (Courchamp et al. 2006). This can create a humangenerated feedback, which can drive species to extinction (Courchamp et al. 2006, Holden and McDonald-Madden 2017). Such a process has been observed in a variety of animal species, including sturgeons (Acipenseridae), where the inflated value placed on rarity has driven increases in price and exploitation (Gault et al. 2008). The net effect and prediction may be that because of the value placed on rarity, spiritual use animals, all other things being equal, would have a higher endangerment status.

Here, we provide the first global overview of medicinal use animals and their threats, as well as an examination of the relationship between rarity (endangerment status) and the specific uses of medicinal animals. We examined data from the International Union on the Conservation of Nature (IUCN) Red List (IUCN 2019) and conducted a complementary literature review. Our objectives were to provide the first global synthesis of medicinal animal use and reveal patterns in use and endangerment. We also tested the following hypotheses: (1) medicinal animal use is prominent in regions with low HDI and high animal diversity; (2) species with multiple uses will have a higher endangerment status and greater threat from human exploitation than those used solely for medicine; and (3) medicinal animals used for spiritual purposes will have a higher endangerment status than those used to treat nonspiritual ailments.

\section{METHODS}

We obtained data from two sources: the IUCN Red List ( $n=658$ species) and a literature search $(n=1140$ species, 96 articles; Append. 1). The criterion for inclusion of papers was explanation of how specific species have a known medicinal use. We crossreferenced these sources to update the use data for species previously not categorized as "medicinal" on the Red List ( $n=$ 697) and added 443 species not present on the Red List to the data set. This resulted in 1660 medicinal species. For species with specific use data, we categorized treatments into spiritual $(n=$ 266) and nonspiritual (i.e., mental or physical, $n=1065$ ) use (Append. 1).We defined spiritual use as animals out of which spiritual or religious objects or ingestible products were created to benefit a user. For example, the skin of the boa constrictor (Boa constrictor) is used in rituals to cleanse bad spirits, as well as in amulets to improve commerce and sexual attraction (Alves et al. 2012a). We used these categories to assess whether specific uses were associated with differing levels of endangerment. Proportions were analyzed for statistical differences using the Fisher's Exact Test.

We examined patterns of endangerment using Red List categories, and additionally examined patterns in threats using a subset of species $(n=320)$ for which threat and stressor data exist. The IUCN provides a threat score, which encompasses scope (proportion of the species population that experiences said threat) and severity (degree of species decline associated with each threat, from causing "very rapid" to "negligible" declines). Stressors are defined as the factors that impose endangerment on species resulting from the above threats. Furthermore, we identified whether medicinal species had listed threats related to exploitation as one way to assess the degree to which medicinal and other uses requiring animal exploitation might impact species.

Finally, we examined coarse spatial patterns in medicinal use animals. The IUCN and BirdLife International (2020) provided polygon shapefiles for species groups (mammals, amphibians, etc.; Append. 1). For each group, we merged the shapefile with our data set to subset species into medicinal use and "at risk" ("Vulnerable" to "Critically Endangered") medicinal use species. We converted these shapefiles to raster surfaces with a resolution of $110 \mathrm{~km}^{2}$, or $\sim 1^{\circ}$ (Scheffers et al. 2019). We calculated the sum of medicinal species in each pixel, the proportion of all animals (with spatial data in the IUCN) in each pixel subject to medicinal use, and proportion of medicinal animals in each pixel that are at risk. The raster layers of all species groups were combined to produce distribution maps. These maps were qualitatively assessed for spatial correlation between medicinal use and HDI. All analyses were performed with R Version 3.6.1.

\section{RESULTS}

Globally, animals used for medicine comprise a relatively narrow subset of all animals, but occur across diverse taxa, habitats, and geographies. Among known species about $77 \%(n=1286)$ are chordates, which represent about $0.03 \%$ of all known phylum members (Fig. 1A). Most species with described habitat are terrestrial $(\sim 72 \%, n=866)$, but freshwater $(\sim 31 \%, n=370)$ and marine $(\sim 22 \%, n=266)$ environments are common. Geographic hotspots of medicinal species occur in South America, Southeast Asia, India, and the Afrotropics (Fig. 2A). Accounting for the number of taxa potentially available for medicinal use in each area, however, reveals regions where high proportions of available animals have medicinal use (Fig. 2B).

Fig. 1. The proportion of medicinal use species in each phylum and IUCN Red List species population trend, shown as a percentage of species in each phylum (A) and proportion of phylum classified according to population trend (B).
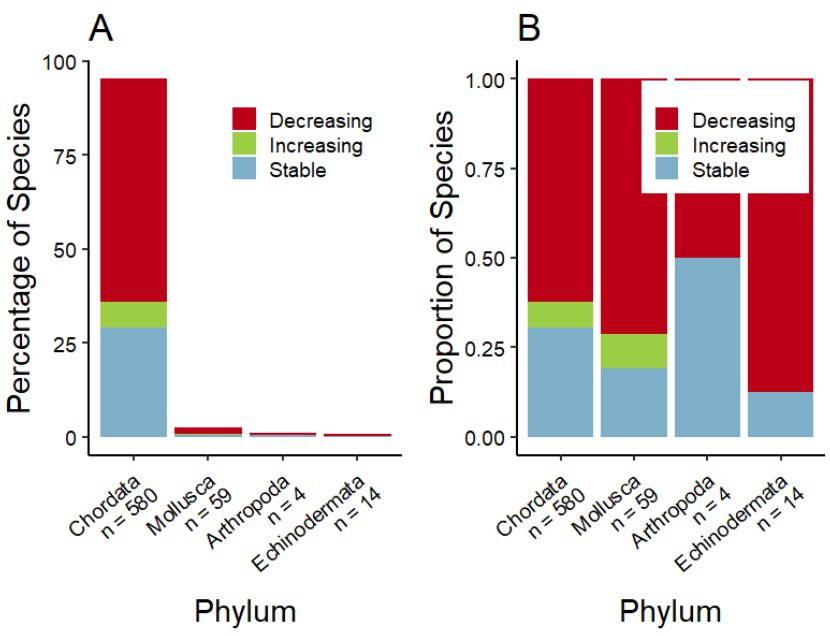
Fig. 2. The number of animal species used for medicine (A), the proportion of animal species used for medicinal purposes (B), and the proportion of those that are at risk ("Vulnerable", "Endangered", or "Critically Endangered") (C).
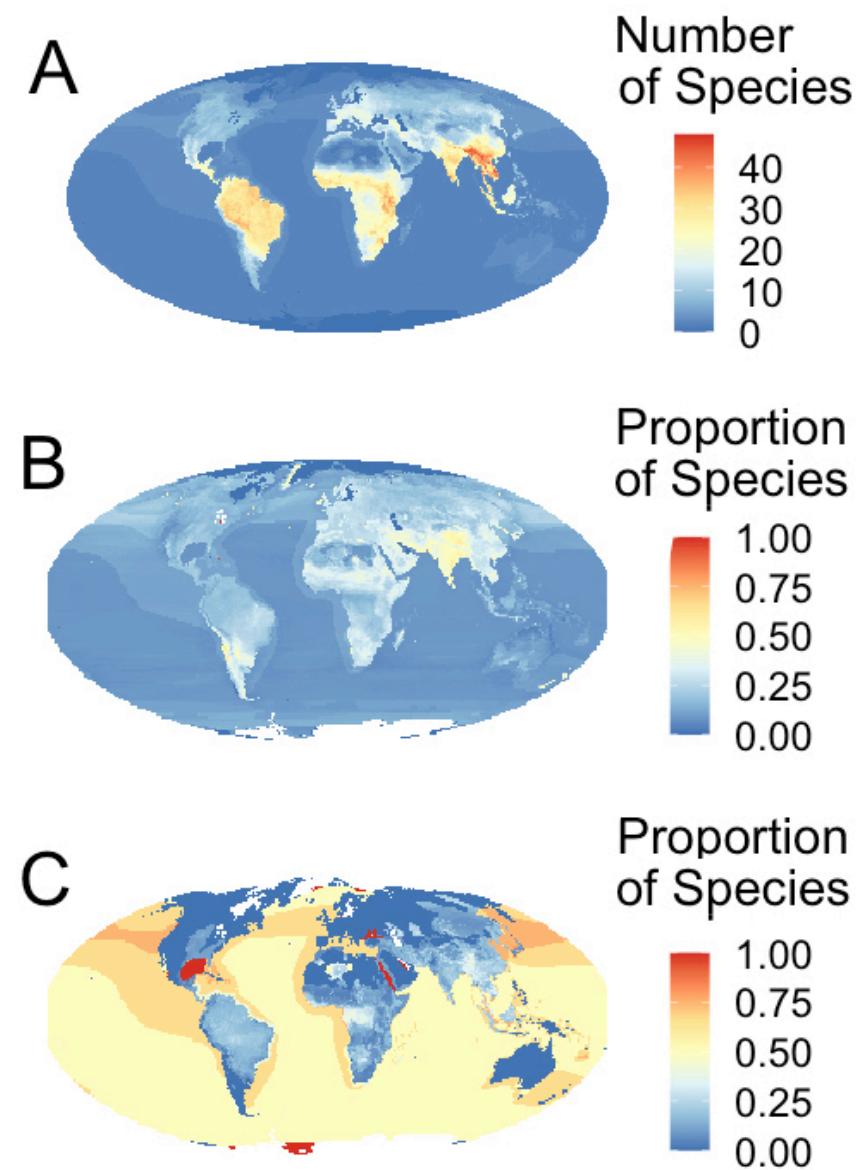

\section{Proportion of Species}

1.00
0.75
0.50
0.25
0.00

Medicinal species vary in conservation status. Among species with known population trends $(n=839)$, the highest proportion have a decreasing trend $(\sim 63 \%, n=525)$, whereas about $30 \%(n=254)$ are stable, and only about $7 \%(n=60)$ have increasing populations (Fig. 1). A significantly higher proportion of species have a decreasing trend than those that show increasing or stable populations (Fisher's Exact Test, $p<0.001)$. A large proportion $(\sim 50 \%)$ of marine species are "at risk" ("Vulnerable" to "Critically Endangered"; Fig. 2C). A particularly high proportion of medicinal animals are at risk in the Black Sea, Red Sea, Persian Gulf, and Gulf of Mexico (Fig. 2C). Of terrestrial species, high proportions of at-risk species occur in the same regions where most medicinal species occur: Southeast Asia, Russia, India, the Afrotropics, and South and Central America (Fig. 2C).

Variation in how medicinal animals are used is associated with their conservation status. At least about $62 \%(n=1025)$ of species have multiple uses. The most common additional use is food for human consumption, which approaches half $(\sim 46 \%, n=769)$. Multiple-use animals are more likely to be at risk than medicinalonly animals $(\sim 26 \%, n=266$ of 1025 , mixed-use species at risk vs. $\sim 8 \%, n=53$ of 635 , medicinal-only species at risk; Fisher's
Exact Test, $p<0.001$; Fig. 3). Additionally, we found that, of atrisk species, a higher proportion have mixed uses $(\sim 83 \%, n=266$ of 319 at-risk species) than solely medicinal uses $(\sim 17 \%, n=53$ of 319). Specific medicinal use also correlated with conservation status. For species with solely medicinal use, species used for spiritual purposes have a significantly higher proportion of atrisk species $(\sim 19 \%, n=19$ of 101$)$ compared with about $6 \%(n=$ 30 of 515) of those used in nonspiritual contexts (Fisher's Exact Test, $p<0.001$; Fig. 4).

Fig. 3. Percentage of medicinal use species with medicinal use only or mixed use by Red List Category. (NL: Not listed, DD: Data Deficient, LC: Least Concern, NT: Near Threatened, VU: Vulnerable, EN: Endangered, CR: Critically Endangered, EX: Extinct).

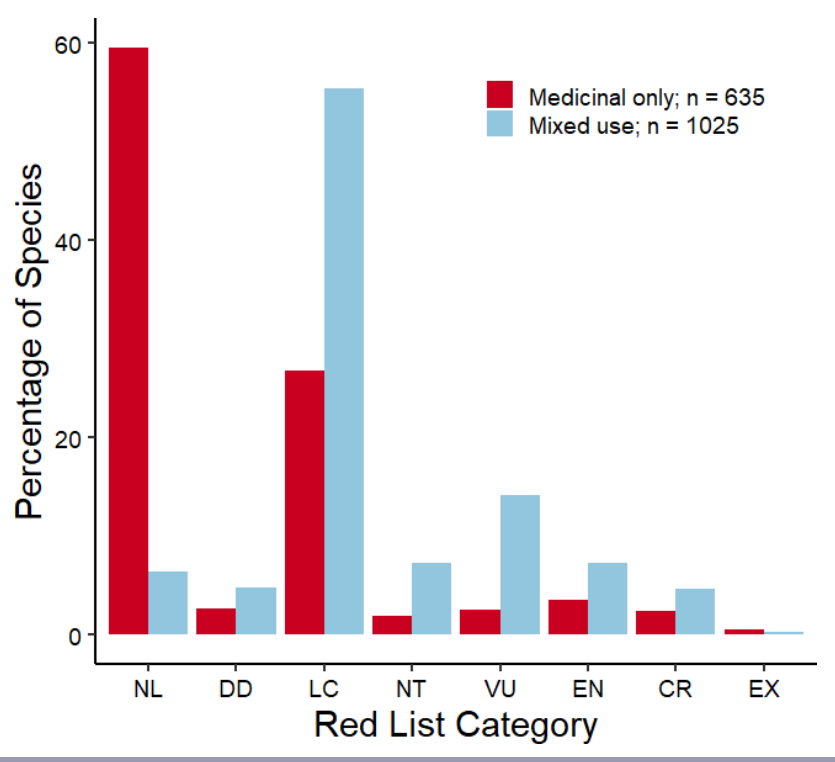

Fig. 4. Percentage of spiritual and nonspiritual use animals by Red List Category (NL: Not listed, DD: Data Deficient, LC: Least Concern, NT: Near Threatened, VU: Vulnerable, EN: Endangered, CR: Critically Endangered, EX: Extinct) for all species with use data (A) and for species only used medicinally (B).
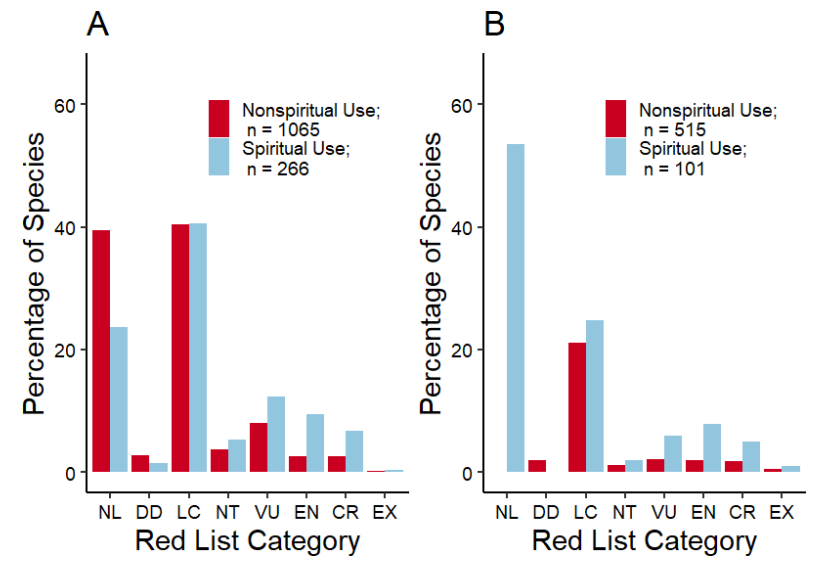
Threats were varied, many carrying primarily low impact, with few species experiencing moderate or high impacts (Fig. 5). Primary threats related to agriculture and aquaculture $(\sim 45 \%$ of species, $n=143)$ and biological resource use $(\sim 4 \%, n=142$; Fig. $6)$, which includes exploitation for medicine, food, clothing, and other uses. For species used solely for medicine $(n=76$ species with threat data), agriculture and aquaculture $(\sim 41 \%, n=31)$ and biological resource use $(\sim 45 \%, n=34)$ pose threats for similar proportions of species. Inspecting data on specific uses, we found that approximately $38 \%(n=628)$ of all medicinal use species are threatened by human exploitation (e.g., hunting, fishing; Append. $1)$. Of species used solely for medicine $(n=635)$, however, exploitation is considered a threat for only about $12 \%(n=75)$. Of all at-risk medicinal use species (including those with mixed uses, $n=319)$, about $86 \%(n=275)$ have a threat of human exploitation.

Fig. 5. Percentage of medicinal use animals by threat score. RCD: Residential or Commercial Development, CCSW: Climate Change and Severe Weather, GE: Geological Events, POL: Pollution, IOP: Invasive and other problematic species, genes, and diseases, NSM: Natural System Modification, HID: Human Intrusion and Disturbance, BRU: Biological Resource Use, TSC: Transportation and Service Corridors, EPM: Energy Production and Mining, AG: Agriculture and Aquaculture. Other threats were excluded due to negligible proportions.

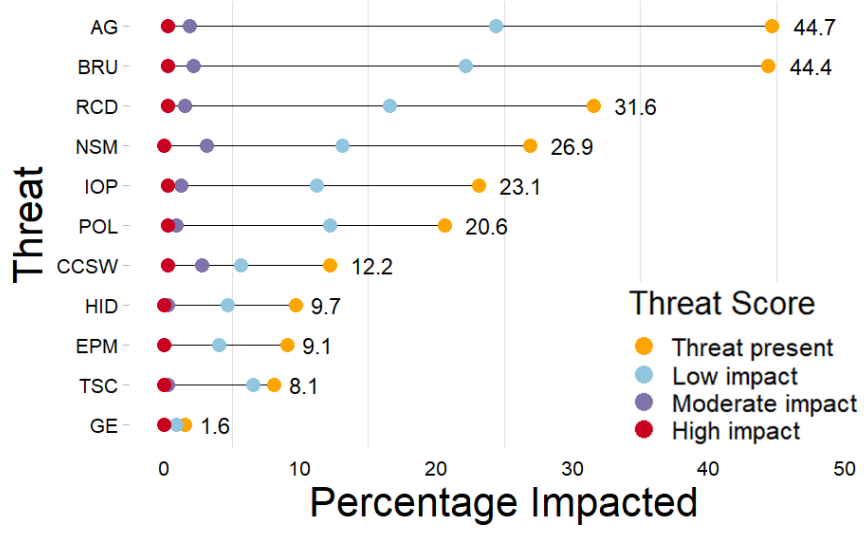

Top stressors were primarily related to ecosystem degradation ( $74 \%$ of species, $n=221)$ and ecosystem conversion $(\sim 63 \%, n=$ 188). Ecosystem degradation and conversion impose stress on significantly more species than direct species mortality $(\sim 4 \%, n$ $=140$, Fisher's Exact Test, $p<0.001$; Fig. 6). For species used solely for medicine ( $n=72$ species with stress data), ecosystem degradation $(\sim 78 \%, n=56)$ and conversion $(\sim 60 \%, n=43)$ pose top stressors, with mortality imposing a stress for about $51 \%(n$ =37).

\section{DISCUSSION}

We found that the use and conservation status of medicinal animals varies globally, but distinct patterns emerged. Although medicinal animal use is widespread, regional use generally maps inversely to human development and positively to associated animal diversity. Within-range variation in medicinal animal use is likely common given variation in Indigenous populations, cultural groups, habitat availability, and access to Western health care (Alves and Rosa 2007b). However, in general, hotspots of use occur in biodiverse regions with low HDI, such as Brazil and Southeast Asia. We also found that species with multiple uses have increased likelihood of higher endangerment and threat from exploitation compared with species used solely for medicine. Such patterns indicate that medicinal use does not comprise a primary threat for most species. Finally, aligning with predictions from the AAE, we found that spiritual use animals are more likely to have a higher endangerment status than nonspiritual use animals.

Fig. 6. Percentage of medicinal use animals subject to each stressor. Other stressors were excluded due to negligible proportions.

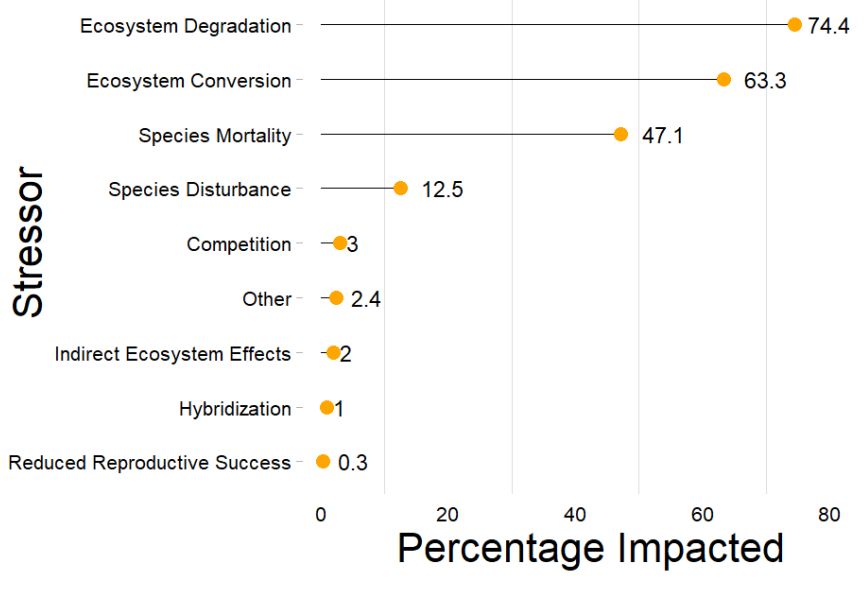

We acknowledge several limitations. First, medicinal use data are surely incomplete. Of the species identified by our literature search, only 139 species ( $12 \%)$ were classified as "medicinal" by the IUCN. Additionally, species assessed by the IUCN may have a bias toward larger or more common fauna, as well as economically important species, which may result in other groups, such as reptiles, being underassessed (Meiri and Chapple 2016). This poses a particular limitation for regions - such as the Cape Floristic Region, South Africa-where medicinal species consist primarily of reptile species (Petersen et al. 2012). Plus, we limited our inclusion of articles to those published in English, which clearly limited the species we considered. Many articles on medicinal animals are published in Spanish, French, Portuguese, and Mandarin, for example. Although this bias suggests that the total number of medicinal species we tabulate is an underestimate, we know of no reason why the limited data set we use would introduce any directional bias to the hypotheses we address. Additionally, data from the literature did not yield information to include in the "multiple use" analysis, nor did they include threat data. Consequently, the proportion of medicinal species with mixed uses may also be an underestimate. Moreover, the effects of colonization by colonial empires likely greatly reduced medicinal animal use in many parts of the world (Langton 2003), making contemporary use more difficult to identify by the IUCN and other researchers. Additionally, threat data from the IUCN were coarse, which restricted our ability to understand how threats from the "biological resource use" category might directly relate to medicinal use. Whereas we expect that most animals showing this threat would primarily be derived from exploitation for food, 
we cannot rule out medicinal-seeking harvest as a primary or additional activity. For species where both medicinal and an additional use were known, our mixed-use analysis provided evidence that species used for medicine alone are not often threatened. Finally, our classification of specific medicinal uses (spiritual vs. nonspiritual) was subjective and primarily obtained for species identified in our literature search, given that such details are largely absent in the IUCN database.

Despite these limitations, broad associations suggest that the spatial distribution of medicinal use relates to the development categorization of the region. In general, higher use of medicinal animals occurs in regions of low to moderate HDI (0.35-0.76), like in Brazil, Bolivia, the Afrotropics, India, and Southeast Asia (UNDP 2018; Fig. 2). One exception is the southern regions of China, which have high medicinal animal use but relatively high HDI ( 0.94). Such discrepancy might relate to rapid development in a region that still retains a strong cultural use of traditional medicines from animals. Given data and analytical limitations, teasing apart the relative quantitative associations of biodiversity and HDI (themselves related) with medicinal species use is not possible. These patterns nonetheless collectively support our hypothesis that regions with higher animal diversity and lower HDI host more medicinal animals.

Although medicinal animal use is widespread, certain taxa and areas have particularly high use. In some regions, small numbers of animals are used, but constitute a large proportion of animal species in that area (Fig. 2A, B). For example, along the coast of Greenland, very few species are used for medicine, but they comprise almost half of the species in the region. In contrast, in Brazil there are up to 33 species used for medicinal purposes, which comprises only about a quarter of the species available (Fig. 2A, B). Southern Asia shows the highest proportion of medicinal animals, likely a result of the long history and continued use of medicinal animals in the region.

Similar to patterns in use, there are distinct patterns in endangerment. Broadly, we found that most medicinal species evaluated have declining population trends. Such a pattern likely relates to the prominence among medicinal species of terrestrial chordates, which are commonly threatened from other means such as habitat destruction (McKee et al. 2004, Lenzen et al. 2012, Scheffers et al. 2019). We suggest, however, that marine and freshwater species ( $38 \%$ combined) must also be considered in conservation efforts of medicinal use species. Notably, from a spatial perspective, the highest proportions of medicinal species that are at risk occur in marine environments (Fig. 2C). This likely relates to the intense exploitation of marine fisheries for human consumption, particularly commercial harvests, which typically exploit at levels far higher than those in terrestrial environments (Rosenberg 2003, Darimont et al. 2015). The highest proportion of marine at-risk species occur in water bodies that are flanked by lands with high human densities and associated food requirements (Fig.2C). Exceptions to this general pattern, such as the hot spot near Antarctica, likely result from the resolution of spatial data (Append. 1: Methods).

We also detected patterns in endangerment that related to specific use of, and threats to, animals, which support our hypothesis that multiple-use species will have a higher endangerment status and threats from exploitation. We found that multiple-use species have a significantly higher proportion of species classified at a higher endangerment status or with a threat of exploitation than those used solely for medicine. This suggests that medicinal use is not a primary cause of exploitation for medicinal species. Finally, we found agriculture and aquaculture $(\sim 45 \%)$ and biological resource use $(\sim 44 \%)$ impact the highest proportions of medicinal species, with the associated stressors of ecosystem degradation $(\sim \% 74)$, conversion $(\sim 63 \%)$, and species mortality $(\sim 47 \%)$. Ecosystem degradation and conversion result in habitat loss, which represents one of the top threats to biodiversity globally (Lawler et al. 2013, Joppa et al. 2016). We found that ecosystem degradation comprises a threat for a significantly higher proportion of medicinal species than does direct species harvest. Collectively, these patterns provide multiple lines of evidence that medicinal use alone does not comprise a widespread risk to animal populations.

Spiritual use of medicinal animals, however, may be associated with a higher risk of endangerment. Consistent with our predictions, spiritual use species have a higher proportion of atrisk species than nonspiritual use species. Spiritual use animals are often valued for their perceived power (Alves et al. 2013), which, as discussed by Courchamp et al. (2006), can be related to their rarity. It is unclear, however, how often such spiritual use has caused endangerment or how often spiritual use becomes more prominent (and thus recorded) for animals already endangered. Regardless, knowledge about the spiritual use of animals may offer a compelling argument to acquire protection for these species, especially if subject to additional stressors.

Understanding the local uses of animals and the threats these animals face can be vital in developing management strategies that protect biodiversity and peoples in ways that do not impede local and traditional practices (Alves and Souto, 2015, Martinez, 2013). Specifically, local beliefs and uses of medicinal species can have large influence on the success of any conservation strategies (Alves 2012). Medicinal use, however, comprises only one of many ways that humans and animals influence one another. For example, van Vlient et al. (2017) summarized the links between bushmeat and health, with a focus on medicinal, nutritional, and zoonotic dimensions of exploited wildlife in tropical and subtropical forest regions. Regardless of benefits and costs, such species are a vital source of cultural importance that relies on healthy wild populations (Martinez 2013).

As the first global synthesis of medicinal animal use, we have provided an overview of medicinal species and their associated threats. Broadly, despite attention focused on unsustainable exploitation of some medicinal species, our analyses reveal that these represent a small proportion of all medicinal species, most of which face more pronounced threats from multiple uses and ecosystem change. Moreover, specific taxonomic and spatial details from our work can be applied to inform plans aimed at mitigating threats impacting these species as well as important cultural relationships. So-called biocultural approaches can help ensure that local people are considered in conservation planning (Sterling et al. 2017). By taking into account local values and needs relating to medicinal animals, these species could attract new forms of protection from primary threats such as habitat loss. International frameworks and actors that use such evidence to address and implement related planning include the United 
Nations Educational, Scientific and Cultural Organization's Convention for the Safeguarding of the Intangible Cultural Heritage, or the United Nations Declaration on the Rights of Indigenous Peoples. Following a biocultural approach, such efforts require the central participation of local governance structures, which have the agency and knowledge to design, monitor, and enforce any new conservation plans. By limiting the additional threats to medicinal animals, bioculturally oriented planning can safeguard not only medicinal animals but also the intertwined ecological and cultural systems in which they are embedded.

Responses to this article can be read online at: https://www.ecologyandsociety.org/issues/responses. $\mathrm{php} / 12174$

\section{Acknowledgments:}

MLS was funded by the Jamie Cassels Undergraduate Research Award and the NSERC Undergraduate Student Research Award. CTD was supported by an NSERC Discovery Grant. We thank Mathieu Bourbonnais for his technical support throughout this project. We have no conflicts of interest to declare.

\section{Data Availability:}

The data and code that support the findings of this study are available on GitHub at https://github.com/Monica972/Supplementarycode

\section{LITERATURE CITED}

Alves, R. 2012. Relationship between fauna and people and the role of ethnozoology in animal conservation. Ethnobiology and Conservation 1:1-69. https://doi.org/10.15451/ec2012-8-1.2-1-69

Alves, R. R. N., and R. R. D. Barboza. 2010. A global overview of canids used in traditional medicines. Biodiversity and Conservation 19:1513-1522. https://doi.org/10.1007/s10531-010-9805-1

Alves, R. R. da N., W. L. da Silva Vieira, and G. G. Santana. 2008. Reptiles used in traditional folk medicine: conservation implications. Biodiversity and Conservation 17:2037-2049. https:// doi.org/10.1007/s10531-007-9305-0

Alves, R. R. N., M. F. T. Medeiros, U. P. Albuquerque, and I. L. Rosa. 2013. From past to present: medicinal animals in a historical perspective. Pages 11-23 in R. R. Alves and I. L. Rosa, editors. Animals in traditional folk medicine: implications for conservation. Springer-Verlag, Berlin Heidelberg, Germany. https://doi. org/10.1007/978-3-642-29026-8 2

Alves, R. R. N., T. P. R., Oliveira, and M. F. T. Medeiros. 2017. Trends in medicinal uses of edible wild vertebrates in Brazil. Evidence Based Complementary Alternative Medicine 2017: 4901329. https://doi.org/10.1155/2017/4901329

Alves, R. R., and I. L. Rosa. 2005. Why study the use of animal products in traditional medicines? Journal of Ethnobiology and Ethnomedicine 1: 5.
Alves, R. R., and I. M. Rosa. 2007a. Biodiversity, traditional medicine and public health: where do they meet? Journal of Ethnobiology and Ethnomedicine 3: 14. https://doi. org/10.1186/1746-4269-3-14

Alves, R. R. N., and I. L. Rosa. 2007b. Zootherapeutic practices among fishing communities in North and Northeast Brazil: a comparison. Journal of Ethnopharmacology 111:82-103. https:// doi.org/10.1016/j.jep.2006.10.033

Alves, R. R. N., I. L. Rosa, N. A. Leo Neto, and R. Voeks. $2012 a$. Animals for the gods: magical and religious faunal use and trade in Brazil. Human Ecology 40:751-780. https://doi.org/10.1007/ s10745-012-9516-1

Alves, R. R. N., and W. M. S. Souto. 2015. Ethnozoology: a brief introduction. Ethnobiology and Conservation 4:1-13. https://doi. org/10.15451/ec2015-1-4.1-1-13

Alves, R. R. N., W. M. S. Souto, and R. R. D. Barboza. 2010. Primates in traditional folk medicine: a world overview. Mammal Review 40:155-180. https://doi.org/10.1111/j.1365-2907.2010.00158. $\underline{\mathrm{X}}$

Alves, Rômulo R. N., W. M. S. Souto, R. E. M. C. C. Oliveira, R. R. D. Barboza, I. L. Rosa. 2012b. Aquatic mammals used in traditional folk medicine: a global analysis. Pages 241-251 in R. R. Alves and I. L. Rosa, editors. Animals in traditional folk medicine: implications for conservation. Springer-Verlag, Berlin Heidelberg, Germany. https://doi.org/10.1007/978-3-642-29026-8_11

BirdLife International. 2020. Data Zone. BirdLife International. [online] URL: http://datazone.birdlife.org/species/requestdis

Boakye, M. K., D. W. Pietersen, A. Kotzé, D. L. Dalton, and R. Jansen. 2014. Ethnomedicinal use of African pangolins by traditional medical practitioners in Sierra Leone. Journal of Ethnobiology and Ethnomedicine 10: 76. https://doi. org/10.1186/1746-4269-10-76

Boakye, M. K., D. W. Pietersen, A. Kotze, D.-L. Dalton, and R. Jansen. 2015. Knowledge and uses of African pangolins as a source of traditional medicine in Ghana. Plos One 10(1): e0117199. https://doi.org/10.1371/journal.pone.0117199

Cheng, W., S. Xing, and T. C. Bonebrake. 2017. Recent pangolin seizures in China reveal priority areas for intervention. Conservation Letters 10:757-764. https://doi.org/10.1111/conl.12339

Cheung, H., L. Mazerolle, H. P. Possingham, and D. Biggs. 2018. Medicinal use and legalized trade of rhinoceros horn from the perspective of traditional Chinese medicine practitioners in Hong Kong. Tropical Conservation Science 11:1-8. https://doi. org/10.1177/1940082918787428

Courchamp, F., E. Angulo, P. Rivalan, R. J. Hall, L. Signoret, L. Bull, and Y. Meinard. 2006. Rarity value and species extinction: the anthropogenic Allee effect. PLOS Biology 4: e415. https://doi. org/10.1371/journal.pbio.0040415

Darimont, C. T., C. H. Fox, H. M. Bryan, and T. E. Reimchen. 2015. The unique ecology of human predators. Science 349 (6250):858-860. https://doi.org/10.1126/science.aac4249

de Figueiredo, R. E. C. R., A. Vasconcellos, I. S. Policarpo, I.S., and R. R. N. Alves. 2015. Edible and medicinal termites: a global 
overview. Journal of Ethnobiology and Ethnomedicine 11: 29. https://doi.org/10.1186/s13002-015-0016-4

Gault, A., Y. Meinard, and F. Courchamp. 2008. Consumers' taste for rarity drives sturgeons to extinction. Conservation Letters 1:199-207. https://doi.org/10.1111/j.1755-263X.2008.00038.x

Graham-Rowe, D. 2011. Biodiversity: endangered and in demand. Nature 480:S101-S103. https://doi.org/10.1038/480S101a

Hall, J. 2019. Traditional Chinese medicine and wildlife. National Geographic. [online] URL: https://www.nationalgeographic. com/animals/reference/traditional-chinese-medicine/

Holden, M. H., and E. McDonald-Madden. 2017. High prices for rare species can drive large populations extinct: the anthropogenic Allee effect revisited. Journal of Theoretical Biology 429:170-180. https://doi.org/10.1016/j.jtbi.2017.06.019

International Union for Conservation of Nature (IUCN). 2019. The IUCN red list of threatened species. Version 2019-1. [online] URL: https://www.iucnredlist.org.

Jacobo-Salcedo, M. del R., A. J. Alonso-Castro, and A. ZarateMartinez. 2011. Folk medicinal use of fauna in Mapimi, Durango, México. Journal of Ethnopharmacology 133:902-906. https://doi.org/10.1016/j.jep.2010.10.005

Joppa, L. N., B. O’Connor, P. Visconti, C. Smith, J. Geldmann, M. Hoffmann, J. E. M. Watson, S. H. M. Butchart, M. VirahSawmy, B. S. Halpern, S. E. Ahmed, A. Balmford, W. J. Sutherland, M. Harfoot, C. Hilton-Taylor, W. Foden, E. D. Minin, S. Pagad, P. Genovesi, J. Hutton, and N. D. Burgess. 2016. Filling in biodiversity threat gaps. Science 352(5284):416-418. https://doi.org/10.1126/science.aaf3565

Langton, M. 2003. The "wild", the market and the native: indigenous people face new forms of global colonization. Pages 79-107 in W. M. Adams and M. Mulligan, editors. Decolonizing nature: strategies for conservation in a post-colonialera. Earthscan, London, UK. https://doi.org/10.1093/oso/9780199264520.003.0014

Lawler, J., J. Aukema, J. Grant, B. Halpern, P. Kareiva, C. Nelson, K. Ohleth, J. Olden, M. Schlaepfer, B. Silliman, and P. Zaradic. 2013. Conservation science: a 20-year report card. Frontiers in Ecology and the Environment 4:473-480. https://doi.org/10.1890/1540-9295 (2006)4[473:CSAYRC]2.0.CO;2

Lenzen, M., D. Moran, K. Kanemoto, B. Foran, L. Lobefaro, and A. Geschke. 2012. International trade drives biodiversity threats in developing nations. Nature 486:109-112. https://doi. org/10.1038/nature11145

Liu, Z., Z. Jiang, H. Fang, C. Li, A. Mi, J. Chen, X. Zhang, S. Cui, D. Chen, X. Ping, F. Li, C. Li, S. Tang, Z. Luo, Y. Zeng, and Z. Meng. 2016. Perception, price and preference: consumption and protection of wild animals used in traditional medicine. PLoS ONE 111(3): e0145901. https://doi.org/10.1371/journal.pone.0145901

Martínez, G. J. 2013. Use of fauna in the traditional medicine of native Toba (qom) from the Argentine Gran Chaco region: an ethnozoological and conservationist approach. Ethnobiology and Conservation 2: 2. https://doi.org/10.15451/ec2013-8-2.2-1-43
McKee, J. K., P. W. Sciulli, C. D. Fooce, and T. A. Waite. 2004. Forecasting global biodiversity threats associated with human population growth. Biological Conservation 115:161-164. https:// doi.org/10.1016/S0006-3207(03)00099-5

Meiri, S., and D. G. Chapple. 2016. Biases in the current knowledge of threat status in lizards, and bridging the 'assessment gap.' Biological Conservation 204:6-15. https://doi.org/10.1016/j. biocon.2016.03.009

Petersen, L. M., E. J. Moll, R. Collins, and M. T. Hockings. 2012. Development of a compendium of local, wild-harvested species used in the informal economy trade, Cape Town, South Africa. Ecology and Society 17(2): 26. https://doi.org/10.5751/ ES-04537-170226

Ripple, W. J., C. Wolf, T. M. Newsome, M. G. Betts, G. Ceballos, F. Courchamp, M. W. Hayward, B. Van Valkenburgh, A. D. Wallach, A.D., and B. Worm. 2019. Are we eating the world's megafauna to extinction? Conservation Letters 12: e12627. https:// doi.org/10.1111/conl.12627

Rosenberg, A. A. 2003. Managing to the margins: the overexploitation of fisheries. Frontiers in Ecology and the Environment 1:102-106. https://doi.org/10.1890/1540-9295(2003) 001[0102:MTTMTO]2.0.CO;2

Scheffers, B. R., B. F. Oliveira, I. Lamb, and D. P. Edwards. 2019. Global wildlife trade across the tree of life. Science 366 (6461):71-76. https://doi.org/10.1126/science.aav5327

Soewu, D. A., and I. A. Ayodele. 2009. Utilisation of pangolin (Manis sps) in traditional Yorubic medicine in Ijebu province, Ogun State, Nigeria. Journal of Ethnobiology and Ethnomedicine 5: 39. https://doi.org/10.1186/1746-4269-5-39

Stangeland, T., S. S. Dhillion, and H. Reksten. 2008. Recognition and development of traditional medicine in Tanzania. Journal of Ethnopharmacology 117:290-299. https://doi.org/10.1016/j.jep.2008.02.008

Sterling, E. J., C. Filardi, A. Toomey, A. Sigouin, E. Betley, N. Gazit, J. Newell, S. Albert, D. Alvira, N. Bergamini, M. Blair, D. Boseto, K. Burrows, N. Bynum, S. Caillon, J. E. Caselle, J. Claudet, G. Cullman, R. Dacks, P. B. Eyzaguirre, S. Gray, J. Herrera, P. Kenilorea, K. Kinney, N. Kurashima, S. Macey, C. Malone, S. Mauli, J. McCarter, H. McMillen, P. Pascua, P. Pikacha, A. L. Porzecanski, P. de Robert, M. Salpeteur, M. Sirikolo, M. H. Stege, K. Stege, T. Ticktin, R. Vave, A. Wali, P. West, K. B. Winter, and S. D. Jupiter. 2017. Biocultural approaches to well-being and sustainability indicators across scales. Nature Ecology and Evolution 1:1798-1806. https://doi.org/10.1038/s41559-017-0349-6

Stromberg, J., and S. Zielinski. 2011. Ten threatened and endangered species used in traditional medicine. Smithsonian Magazine. [online] URL: https://www.https://www.smithsonianmag. com/science-nature/ten-threatened-and-endangered-species-usedin-traditional-medicine-112814487/

United Nations Development Programme (UNDP). 2018. Human Development Index (HDI). UNDP, New York, New York, USA. [online] URL: http://hdr.undp.org/en/indicators/137506 \# 
van Vliet, N., J. L. Moreno Calderon, J. Gomez, W. Zhou, J. E. Fa, C. Golden, R. R. N. Alves, and R. Nasi. 2017. Bushmeat and human health: assessing the evidence in tropical and sub-tropical forests. Ethnobiology and Conservation 6:1-45.

Yan, D., J. Y. Luo, Y. M. Han, C. Peng, X. P. Dong, S. L. Chen, L. G. Sun, and X. H. Xiao. 2013. Forensic DNA barcoding and bio-response studies of animal horn products used in traditional medicine. Plos One 8: e55854. https://doi.org/10.1371/journal. pone. 0055854 


\section{Appendix}

Supporting information: additional methods and literature

Methods

Data

The IUCN Red List includes information on over 70,000 animal species. Of these, 658 were classified as 'medicinal' use. For IUCN species, we excluded those used only for 'biomedical research' and those that 'may' be used for medicine based on their taxonomic family. We also recorded uses additional to medicine (i.e., food, clothing, etc).

We identified additional species from a literature search using Web of Science and Google Scholar (for search terms and processes, see Figures A1.1, A1.2). One hundred and eighty articles we identified discussed medicinal species use and threats, and 96 offered information about specific medicinal use ( $\mathrm{n}=1140$ species). Our literature review also offered specific medicinal use data not offered in the assessments of the same species listed in the IUCN database. Of 180 studies describing medicinal uses from around the world, 49 occurred in Brazil and 25 occurred in China.

From this list of species identified via the IUCN list and literature search, we categorized use into specific categories. We identified 360 ailments treated by 1151 medicinal animals. We categorized these treatments into spiritual and non-spiritual use. We found that some species ( $\mathrm{n}=$ 180) had both spiritual and non-spiritual uses, and were coded as such in the analysis.

For species listed by the IUCN, we additionally examined patterns of endangerment. The Red List is created by multidisciplinary experts who assess the endangerment status of species as 'Data Deficient,' 'Least Concern,' 'Near Threatened,' 'Vulnerable,' 'Endangered,' 'Critically 
Endangered,' 'Extinct in the Wild,' or 'Extinct' (IUCN 2019). We classified species in the 'Vulnerable,' 'Endangered,' or 'Critically Endangered' categories as 'at-risk' of extinction (Scheffers et al 2019. We also examined patterns in the threats species face with a subset of species $(n=320)$ for which threat data exist. Threat data are unavailable for unlisted species we identified from the literature ( $n=443$ species) as well as 209 of the medicinal IUCN Red List species. Only 44 ( 17\%) of spiritual use species have threat data associated with them. Habitat data was also unavailable for $\sim 27 \%$ of medicinal species.

Finally, we identified if medicinal use species had listed threats related to exploitation as one way to assess the degree to which medicinal, and other uses requiring exploitation of animals, may impact species. Exploitation-related threats included "hunting \& collecting terrestrial animals", "intentional use (species being assessed is the target)", "fishing \& harvesting aquatic resources", "intentional use: subsistence/small scale (species being assessed is the target [harvest]", and "intentional use: large scale (species being assessed is the target)[harvest]".

Spatial distributions

We examined spatial patterns in medicinal use animals. Range data for all species excluding birds were derived from the IUCN. Bird data were downloaded from Bird Life International (BirdLife International 2019). The IUCN provided polygon data classified in groups of mammals, conus, amphibians, lobsters, marine fish, reptiles, sea cucumbers, freshwater species, sharks, rays, and chimaeras. All spatial data were at a species range scale, including migratory ranges. We assumed medicinal use throughout the entire range. Such an assumption could not account for variation in use across potentially many cultural groups, or species that additionally use areas with low or non-existent populations of people. 


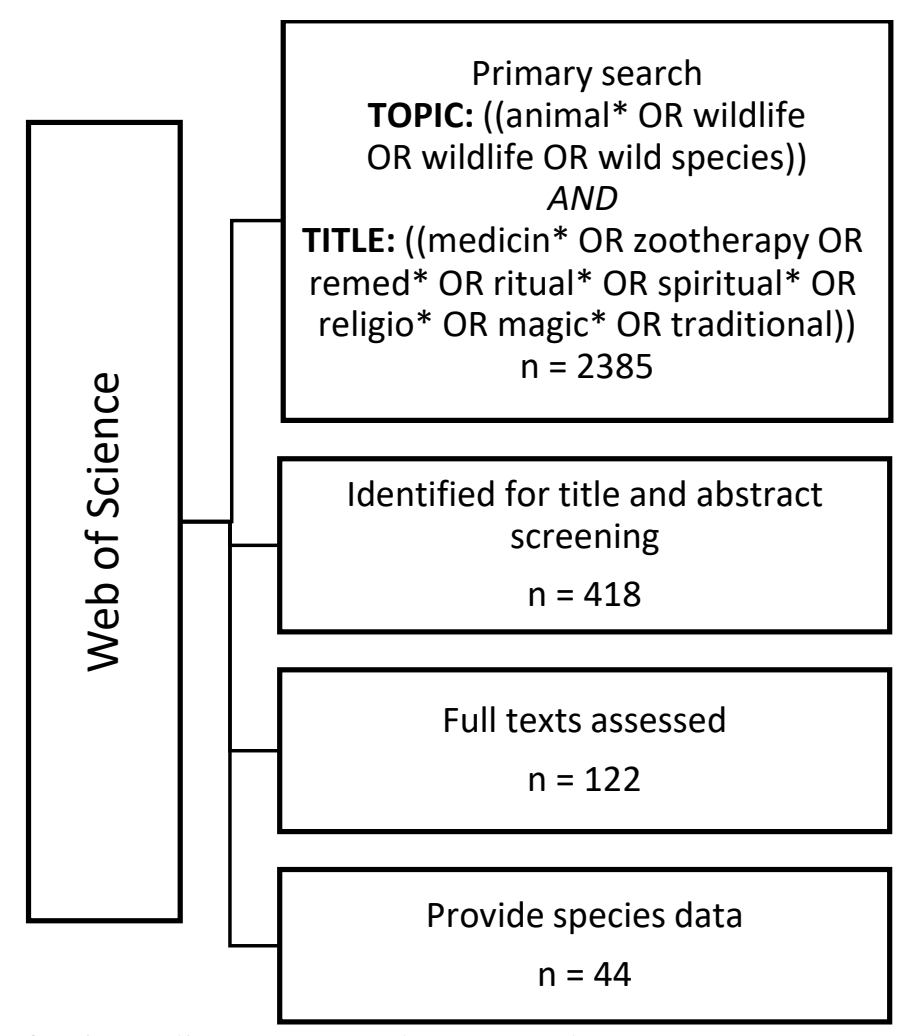

Figure A1.1: Web of Science literature search terms and process.

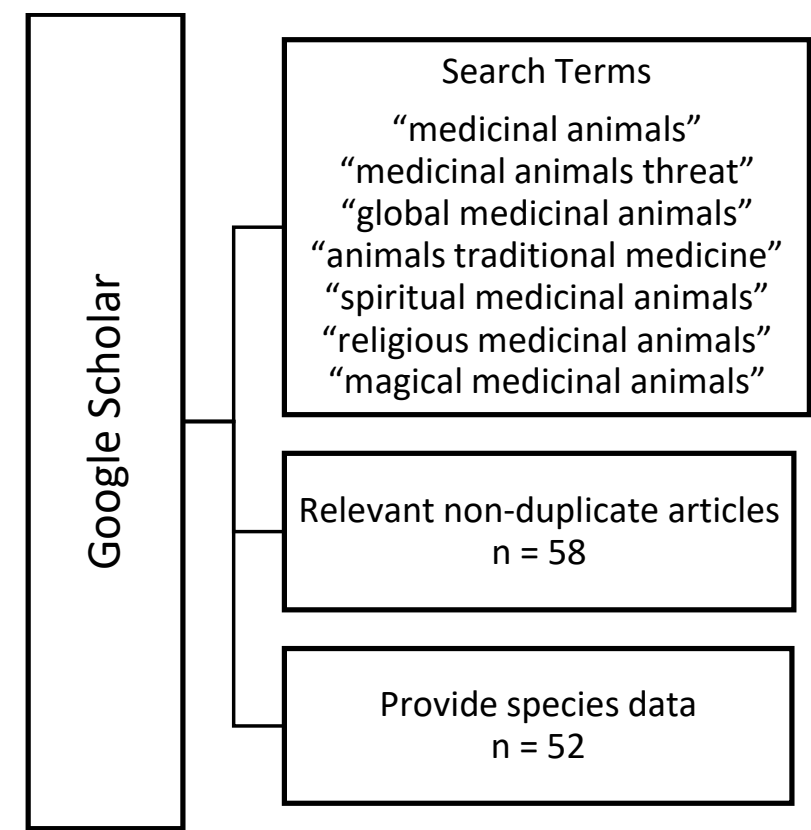

Figure A1.2: Google Scholar literature search terms and process 
Supporting Literature:

The literature below provided the taxonomic and specific use data used in some analyses. Species obtained from each source can be found in the supplementary data file.

[1] Ajagun, E. J., C. E. Anyaku, and M. P. Afolayan. 2017. A survey of the Traditional Medical \& Non-medical Uses of Animals Species \& Parts of the Indigenous people of Ogbomoso; Oyo State. International Journal of Herbal Medicine, 5:26-32.

[2] Alade, G. O., A. Frank, and K. K. Ajibesin. 2018. Animals and animal products as medicines: A survey of Epie-Atissa and Ogbia people of Bayelsa State, Nigeria. Journal of Pharmacy \& Pharmacognosy Research, 6(6):483-502.

[3] Alves, R. R. N. 2009. Fauna used in popular medicine in Northeast Brazil. Journal of Ethnobiology and Ethnomedicine, 5(1):1.

[4] Alves, R. R. N., and H. N. Alves. 2011. The faunal drugstore: Animal-based remedies used in traditional medicines in Latin America. Journal of Ethnobiology and Ethnomedicine, 7(1):9.

[5] Alves, R. R. N., J. A. A. Barbosa, S. L. D. X. Santos, W. M. S. Souto, and R. R. D. Barboza. 2011. Animal-Based Remedies as Complementary Medicines in the Semi-Arid Region of Northeastern Brazil. Evidence-Based Complementary and Alternative Medicine, 1-15.

[6] Alves, R. R. N., I. L. Rosa, N. A. Leo Neto, and R. Voeks. 2012. Animals for the Gods: Magical and Religious Faunal Use and Trade in Brazil. Human Ecology, 40(5):751-780.

[7] Alves, R. R. N., I. L. Rosa, and G. G. Santana. 2007. The role of animal-derived remedies as complementary medicine in Brazil. Bioscience, 57(11):949-955. 
[8] Alves, R. R. N., W. M. S. Souto, and R. R. D. Barboza. 2010. Primates in traditional folk medicine: A world overview. Mammal Review, 402:155-180.

[9] Alves, R. R. N., W. M. S. Souto, R. E. M. C. C. Oliveira, R. R. D. Barboza, and I. L. Rosa. 2012. Aquatic Mammals Used in Traditional Folk Medicine: A Global Analysis. In Animals in Traditional Fold Medicine (pp. 241-261). Springer, Berlin, Heidelberg.

[10] Alves, R. R. N., N. A. L. Neto, S. E. Brooks, and U. P. Albuquerque. 2009.

Commercialization of animal-derived remedies as complementary medicine in the semiarid region of Northeastern Brazil. Journal of Ethnopharmacology, 124(3), 600-608.

[11] Alves, R. R. N., and I. L. Rosa. 2006. From cnidarians to mammals: The use of animals as remedies in fishing communities in NE Brazil. Journal of Ethnopharmacology, 1072: $259-276$.

[12] Alves, R. R. N., and I. L. Rosa. 2007a. Zootherapeutic practices among fishing communities in North and Northeast Brazil: A comparison. Journal of Ethnopharmacology, 111(1):82-103

[13] Alves, R. R. N., and I. L. Rosa. 2007b. Zootherapy goes to town: The use of animalbased remedies in urban areas of NE and N Brazil. Journal of Ethnopharmacology, 113(3):541-555.

[14] Alves, R. R. N., and R. R. D. Barboza. 2010. A Global overview of canids used in traditional medicines. Biodiversity and Conservation, 19(6):1513-1522.

[15] Alves, R. R. N., M. das Graças Gerônimo Oliveira, R. R. D. Barboza, and L. C. S. Lopez. 2010. An ethnozoological survey of medicinal animals commercialized in the markets of Campina Grande, NE Brazil. Human Ecology Review, 17(1):11-17. 
[16] Alves, R. R. N., M. de F. Melo, F. S. Ferreira, D. M. de B. M. Trovão, T. L. P. Dias, J. V. Oliveira, R. F. P. de Lucena, and R. R. D. Barboza. 2016. Healing with animals in a semiarid northeastern area of Brazil. Environment, Development and Sustainability, 18(6):1733-1747.

[17] Alves, R. R. N., R. O. de S. Neta, D. M. de B. Trovão, J. E. de L. Barbosa, A. T. Barros, and T. L. P. Dias. 2012. Traditional uses of medicinal animals in the semi-arid region of northeastern Brazil. Journal of Ethnobiology and Ethnomedicine, 8(1):41.

[18] Alves, R. R. N., T. P. R. Oliveira, and M. F. T. Medeiros. 2017. Trends in Medicinal Uses of Edible Wild Vertebrates in Brazil. Evidence-Based Complementary and Alternative Medicine : ECAM, 2017, 4901329-4901329. PubMed.

[19] Alves, R. R. N., T. P. R. Oliveira, and I. L. Rosa. 2013. Wild Animals Used as Food Medicine in Brazil. Evidence-Based Complementary and Alternative Medicine, 2013:670352.

[20] Apaza, L., R. Godoy, D. Wilkie, E. Byron, O. Huanca, W. Leonard, E. Peréz, V. ReyesGarcía, and V. Vadez. 2003. Markets and the use of wild animals for traditional medicine: A case study among the Tsimane' Amerindians of the Bolivian rain forest. Journal of Ethnobiology, 23:47-64.

[21] Asfora El-Deir, A. C., C. A. Collier, M. S. de Almeida, K. M. de Souza Silva, I. da S. Policarpo, T. A. S. Araujo, R. R. Nobrega Alves, U. P. de Albuquerque, and G. J. Barbosa de Moura. 2012. Ichthyofauna Used in Traditional Medicine in Brazil. EvidenceBased Complementary and Alternative Medicine, 474716. 
[22] Azliza, M. A., H. C. Ong, S. Vikineswary, A. Noorlidah, and N. W. Haron. 2012. Ethnomedicinal Resources Used By the Temuan in Ulu Kuang Village. Studies on EthnoMedicine, 6(1):17-22.

[23] Barbosa, J. A. A., J. O. Aguiar, and R. R. N. Alves. 2018. Medicinal use of animals by hunters in North eastern Brazil. Indian Journal of Traditional Knowledge, 17:485-493.

[24] Barros, F. B., S. A. Varela, H. M. Pereira, and L. Vicente. 2012. Medicinal use of fauna by a traditional community in the Brazilian Amazonia. Journal of Ethnobiology and Ethnomedicine, 8(1):37.

[25] Bauer, A. M. 2009. Geckos in traditional medicine: Forensic implications. Applied Herpetology, 6(1):81-96.

[26] Benítez, G. 2011. Animals used for medicinal and magico-religious purposes in western Granada Province, Andalusia (Spain). Journal of Ethnopharmacology, 137(3):11131123.

[27] Bezerra, D. M. M., H. F. P. de Araujo, Â. G. C. Alves, and R. R. N. Alves. 2013. Birds and people in semiarid northeastern Brazil: Symbolic and medicinal relationships. Journal of Ethnobiology and Ethnomedicine, 9(1):3.

[28] Boakye, M. K., E. D. Wiafe, and M. Y. Ziekah. 2019. Ethnomedicinal use of vultures by traditional medicinal practitioners in Ghana. Ostrich, 902:111-118.

[29] Boakye, M. K., D. W. Pietersen, A. Kotze, D.-L. Dalton, and R. Jansen. 2015. Knowledge and Uses of African Pangolins as a Source of Traditional Medicine in Ghana. Plos One, 10(1):e0117199. 
[30] Borah, M. P., and S. B. Prasad. 2017. Ethnozoological study of animals based medicine used by traditional healers and indigenous inhabitants in the adjoining areas of Gibbon Wildlife Sanctuary, Assam, India. Journal of Ethnobiology and Ethnomedicine, 13(1):39.

[31] Braga-Pereira, F., F. R. Santoro, C. V.-D. Santos, and R. R. N. Alves. 2017. First record of Angola's medicinal animals: A case study on the use of mammals in local medicine in Quiçama National Park. Indian Journal of Traditional Medicine, 16:588-592.

[32] Castillo, L., and A. Ladio. 2018. Zootherapy and rural livestock farmers in semiarid Patagonia: The transfer of animal aptitudes for health. Ethnobiology and Conservation, $8(2019)$.

[33] Chakravorty, J., V. B. Meyer-Rochow, and S. Ghosh. 2011. Vertebrates used for medicinal purposes by members of the Nyishi and Galo tribes in Arunachal Pradesh (North-East India). Journal of Ethnobiology and Ethnomedicine, 7(1):13.

[34] Costa Neto, E. M., and P. C. Motta. 2010. Animal species traded as ethnomedicinal resources in the Federal District; central west region of Brazil. The Open Complementary Medicine Journal, 2:24-30.

[35] Costa Neto, E. M., and M. V. M. Oliveira. 2000. Cockroach is Good for Asthma: Zootherapeutic Practices in Northeastern Brazil. Human Ecology Review, 7:41-51.

[36] Costa-Neto, E. M. 2002. The use of insects in folk medicine in the State of Bahia, northeastern Brazil, with notes on insects reported elsewhere in Brazilian folk medicine. Human Ecology, 302:245-263.

[37] Costa-Neto, E. M. 2005. Entomotherapy, or the Medicinal Use of Insects. Journal of Ethnobiology, 25(1):93-114. 
[38] da Silva Policarpo Brito, I., A. K. M. Borges, S. de Faria Lopes, T. L. P. Dias, and R. R. N. Alves. 2019. Environmental influence on the choice of medicinal animals: A case study from northeastern Brazil. Journal of Ethnobiology and Ethnomedicine, 15(1):55.

[39] Davis, E. O., J. A. Glikman, B. Crudge, V. Dang, M. Willemsen, T. Nguyen, D. O’Connor, and T. Bendixsen. 2019. Consumer demand and traditional medicine prescription of bear products in Vietnam. Biological Conservation, 235:119-127.

[40] dos Santos Teixeira, J. V., J. S. dos Santos, D. H. Areas Guanaes, W. D. da Rocha, and A. Schiavetti. 2020. Uses of wild vertebrates in traditional medicine by farmers in the region surrounding the Serra do Conduru State Park (Bahia, Brazil). Biota Neotropica, 20(1):e20190793.

[41] Ferreira, F. S., U. P. Albuquerque, H. D. M. Coutinho, W. de O. Almeida, and R. R. da N. Alves. 2012. The trade in medicinal animals in northeastern Brazil. Evidence-Based Complementary and Alternative Medicine: ECAM, 2012, 126938-126938. PubMed.

[42] Gbogbo, F., and J. K. Daniels. 2019. Trade in wildlife for traditional medicine in Ghana: Therapeutic values, zoonoses considerations, and implications for biodiversity conservation. Human Dimensions of Wildlife, 24(3):296-300.

[43] González-Marín, R. M., P. Moreno-Casasola, A. A. Castro-Luna, and A. Castillo. 2017. Regaining the traditional use of wildlife in wetlands on the coastal plain of Veracruz, Mexico: Ensuring food security in the face of global climate change. Regional Environmental Change, 17(5):1343-1354.

[44] Hernandez, J., C. M. Campos, and C. E. Borghi. 2015. Medicinal use of wild fauna by mestizo communities living near San Guillermo Biosphere Reserve (San Juan, Argentina). Journal of Ethnobiology and Ethnomedicine, 11(1):15. 
[45] Ibrahim, J. A., I. Muazzam, I. A. Jegede, and O. F. Kunle. 2010. Medicinal plants and animals sold by the "Yan-Shimfidas" of Sabo Wuse in Niger State, Nigeria. African Journal of Pharmacy and Pharmacology, 4(6):386-394.

[46] Jacobo-Salcedo, M. del R., A. J. Alonso-Castro, and A. Zarate-Martinez. 2011. Folk medicinal use of fauna in Mapimi, Durango, México. Journal of Ethnopharmacology, 1332:902-906.

[47] Kendie, F. A., S. A. Mekuriaw, and M. A., Dagnew. 2018. Ethnozoological study of traditional medicinal appreciation of animals and their products among the indigenous people of Metema Woreda, North-Western Ethiopia. Journal of Ethnobiology and Ethnomedicine, 14(1):37.

[48] Khatun, Z., P. Bhuiyan, S. I. Roney, and M. Rahmatullah. 2013. Traditional knowledge on zootherapeutic practices among some folk medicinal practitioners of Bangladesh. American-Eurasian Journal of Sustainable Agriculture, 7:155-161.

[49] Kim, G., H. Kim, and M.-J. Song. 2018. Ethnopharmacological implications of quantitative and network analysis for traditional knowledge regarding the medicinal use of animals by indigenous people in Wolchulsan National Park, Korea. Journal of Ethnopharmacology, 213:1-11.

[50] Kim, H., and M.-J. Song. 2013. Ethnozoological study of medicinal animals on Jeju Island, Korea. Journal of Ethnopharmacology, 146(1):75-82.

[51] Kim, M. E., K. B. Murzagulova, and S. B. Evseeva. 2017. Possibility of natural raw materials use in the formation of adjuvant therapy of tuberculosis: experience of folk medicine, modern state of studies. Pharmacy \& Pharmacology, 5(5):404-421. 
[52] Lawal, O., and A. D. Banjo. 2007. Survey of the usage of arthropods in traditional medicine in southwestern Nigeria. Journal of Entomology, 4:104-112.

[53] Li, Q., H.-J. Li, T. Xu, H. Du, C.-L. H. Gang, G. Fan, and Y. Zhang. 2018. Natural Medicines Used in the Traditional Tibetan Medical System for the Treatment of Liver Diseases. Frontiers in Pharmacology, 9:29.

[54] Lohani, U. 2011. Traditional Uses of Animals among Jirels of Central Nepal. Studies on Ethno-Medicine, 52:115-124.

[55] Loko, L. E. Y., S. Medegan Fagla, A. Orobiyi, B. Glinma, J. Toffa, O. Koukoui, L. Djogbenou, and F. Gbaguidi. 2019. Traditional knowledge of invertebrates used for medicine and magical-religious purposes by traditional healers and indigenous populations in the Plateau Department, Republic of Benin. Journal of Ethnobiology and Ethnomedicine, 15(1):66.

[56] Magige, F. J. 2015. Traditional medicinal uses of small mammal products: A case study of the African savannah hares, crested porcupines and rock hyraxes in Serengeti District, Tanzania. Tanzania Journal of Science, 41(1).

[57] Marwat, S. K., M. A. Khan, Fazal-ur-Rehman, and K. U. Khan. 2013. Medicinal uses of honey (Quranic medicine) and its bee flora from Dera Ismail Khan District, KPK, Pakistan. Pakistan Journal of Pharmaceutical Sciences, 262:307-314.

[58] Mishra, N., S. D. Rout, and T. Panda. 2011. Ethno-zoological studies and medicinal values of Similipal Biosphere Reserve, Orissa, India. African Journal of Pharmacy and Pharmacology, 5(1):6-11.

[59] Nijman, V., and D. Bergin. 2017. Reptiles traded in markets for medicinal purposes in contemporary Morocco. Contributions to Zoology, 86(1):39-50. 
[60] Oliveira, E. S., D. F. Torres, S. E. Brooks, and R. R. N. Alves. 2010. The medicinal animal markets in the metropolitan region of Natal City, northeastern Brazil. Journal of Ethnopharmacology, 130(1):54-60.

[61] Paudyal, R., and N. B. Singh. 2015. Ethno-medicinal Uses of Animals and Plants among the Migratory Tangbetons of Pokhara, Nepal. Journal of Institute of Science and Technology, 19(1).

[62] Pereira, R. F., and P. J. Bartolo. 2016. Traditional Therapies for Skin Wound Healing. Advances in Wound Care, 5(5):208-229.

[63] Quave, C. L., U. Lohani, A. Verde, J. Fajardo, D. Rivera, C. Obon, A. Valdes, and A. Pieroni. 2010. A comparative assessment of zootherapeutic remedies from selected areas in Albania, Italy, Spain, and Nepal. Journal of Ethnobiology, 30(1):92-125.

[64] Ramires, M., M. M. Rotundo, and A. Begossi. 2012. The use of fish in Ilhabela (Sao Paulo/Brazil): Preferences, food taboos and medicinal indications. Biota Neotropica, 12(1):21-29.

[65] Rodrigues, E. 2006. Plants and animals utilized as medicines in the Jaú National Park (JNP), Brazilian Amazon. Phytotherapy Research, 20(5):378-391.

[66] Rosa, I. L., G. R. Defavari, R. R. N. Alves, and T. P. R. Oliveira. 2012. Seahorses in Traditional Medicines: A Global Overview. In Animals in Traditional Folk Medicine, pp. $207-240$.

[67] Santiago Lemos, I. C., G. de A. Delmondes, A. D. Ferreira dos Santos, E. S. Santos, D. R. de Oliveira, P. R. Leite de Figueiredo, D. de A. Alves, R. Barbosa, I. R. Alencar de Menezes, H. D. Melo Coutinho, M. R. Kerntopf, and G. P. Fernandes. 2016. Ethnobiological survey of plants and animals used for the treatment of acute respiratory 
infections of children of a traditional community in the municipality of Barbalha, Ceara, Brazil. African Journal of Traditional Complementary and Alternative Medicines, 13(4):166-175.

[68] Seixas, C. S. 2001. Ethnozoology of fishing communities from Ilha Grande (Atlantic Forest Coast; Brazil). Journal of Ethnobiology, 21:107-135.

[69] Soewu, D. 2008. Wild animals in ethnozoological practices among the Yorubas of southwestern Nigeria and the implications for biodiversity conservation. African Journal of Agricultural Research, 3:421-427.

[70] Soewu, D. A., and I. A. Ayodele. 2009. Utilisation of Pangolin (Manis sps) in traditional Yorubic medicine in Ijebu province, Ogun State, Nigeria. Journal of Ethnobiology and Ethnomedicine, 5(1):39.

[71] Sreekeesoon, D. P., and M. F. Mahomoodally. 2014. Ethnopharmacological analysis of medicinal plants and animals used in the treatment and management of pain in Mauritius. Journal of Ethnopharmacology, 157:181-200.

[72] Timothy, S. K., D. U. Habib, and A. E. Ayodeji. 2018. Survey of zoological materials used in traditional medicine in Sabon Gari and Zaria Local Government Areas, Kaduna State, Nigeria. Journal of Complementary Medicine Research, 8(1):32-39.

[73] Vats, R., and S. Thomas. 2015. A study on use of animals as traditional medicine by Sukuma Tribe of Busega District in North-western Tanzania. Journal of Ethnobiology and Ethnomedicine, 11(1):38.

[74] Verma, A., S. Prasad, T. Rongpi, and J. Arjun. 2014. Traditional healing with animals (zootherapy) by the major ethnic group of Karbi Anglong district of Assam, India. International Journal of Pharmacy and Pharmaceutical Sciences, 6. 
[75] Vijayakumar, S., J. E. Morvin Yabesh, S. Prabhu, M. Ayyanar, and R. Damodaran. 2015. Ethnozoological study of animals used by traditional healers in Silent Valley of Kerala, India. Journal of Ethnopharmacology, 162:296-305.

[76] Vijayakumar, S., S. Prabhu, J. E. Morvin Yabesh, and R. Pragashraj. 2015. A quantitative ethnozoological study of traditionally used animals in Pachamalai hills of Tamil Nadu, India. Journal of Ethnopharmacology 171:51-63.

[77] Vyas, N., M. M. Mahawar, and D. P. Jaroli. 1970. Traditional Medicines Derived from Domestic Animals Used by Rebari Community of Rajasthan, India. Our Nature, 7(1).

[78] Wang, D. Q.-H., and M. C. Carey. 2014. Therapeutic uses of animal biles in traditional Chinese medicine: An ethnopharmacological, biophysical chemical and medicinal review. World Journal of Gastroenterology, 2029:9952-9975.

[79] Yeshi, K., P. Morisco, and P. Wangchuk. 2017. Animal-derived natural products of Sowa Rigpa medicine: Their pharmacopoeial description, current utilization and zoological identification. Journal of Ethnopharmacology, 207:192-202.

[80] Yirga, G., M. Teferi, and Y. Gebreslassea. 2011. Ethnozoological study of traditional medicinal animals used by the people of Kafta-Humera District; Northern Ethiopia. International Journal of Medicine and Medical Sciences, 3:316-320.

[81] Zimian, D., Z. Yonghua, and G. Xiwu. 1997. Medicinal insects in China. Ecology of Food and Nutrition, 36:209-220. 